\title{
COMPETITIVENESS STRATEGIES AND TACTICS FOR THE INTERNATIONAL SCIENTIFIC - ACADEMiC Associations ANd Clusters
}

\author{
PoPA, H.L.; MOCAN, M.L.; IZVERCIANU, M. \& PATER, L.R.
}

Abstract: The coopetition among International Academic and Research \& Development Associations $\{I A R D A\}$ and among clusters requires the development and implementation of a new innovative and integrative management of the competitiveness. For the $\{I A R D A\}$ and clusters have not been yet rigorously studied the specific ways and programs for competitiveness increase. We define the new concept „integrative sustainable competitiveness Kid". We analyse the competitiveness of International Academic and Research \& Development Associations $\{$ IARDA $\}$ in the globalised coopetition of the 21st century. We develop a unitary methodology for the competitiveness strategy and tactics of IARDA and clusters that include International Academic and Research \& Development Associations. The systematic increase of the \{IARDA\} and clusters competitiveness requires the enlargement of multidimensional networks in public - private partnership, including $\{$ IARDA\}, capable to develop the "critical - mass" necessary for the rise of integrative sustainable competitiveness in clusters, sectors, regions, continents and the Earth.

Key words: competitiveness, evaluation, competitiveness strategy, unitary methodology
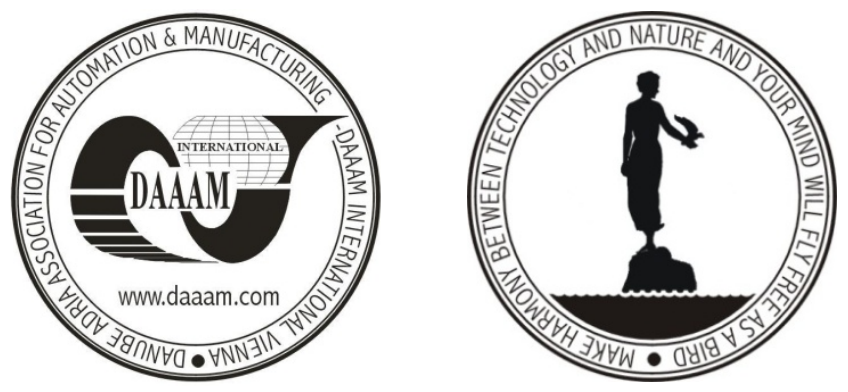

Authors' data: Prof. Popa, H[oria] L[iviu]; Prof. Mocan, M[arian] L[iviu]; Prof. Dean Izvercianu, M[onica]; Pater, L[iana] R[odica], Politehnica University of Timisoara, Management Faculty, 14, Remus Street, 300191, Timisoara, RO, hpopa@eng.upt.ro, mmocan@expertconsulting.ro,mizvercianu@mpt.upt.ro, lianapater@yahoo.com

This Publication has to be referred as: Popa, H[oria] L[iviu]; Mocan, M[arian] L[iviu]; Izvercianu, M[onica] \& Pater, L[iana] R[odica] (2008). Competitiveness Strategies and Tactics for the International Scientific - Academic Associations and Clusters, Chapter 52 in DAAAM International Scientific Book 2008, pp. 613-620, B. Katalinic (Ed.), Published by DAAAM International, ISBN 978-3-901509-66-7, ISSN 1726-9687, Vienna, Austria

DOI: $10.2507 /$ daaam.scibook.2008.52 